\title{
Artikel
}

\section{Van hiv naar corona en van reële kans naar redelijke vrees}

\author{
Mr. dr. N. (Klaas) Rozemond*
}

\section{Inleiding: van restrictie naar extensie}

De hiv-epidemie leidde 18 jaar geleden tot restrictieve rechtspraak van de Hoge Raad over voorwaardelijk opzet bij een met hiv besmette persoon in het geval dat deze persoon onbeschermde seks (seks zonder condoom) heeft met een ander. Volgens de Hoge Raad is de kans op besmetting met het hiv-virus in dergelijke gevallen volgens algemene ervaringsregels niet aanmerkelijk te noemen. Daarom kan de onbeschermde seks niet zonder meer als een poging tot doodslag of een poging tot zware mishandeling worden gekwalificeerd. ${ }^{1}$ Ook bij bewezen besmetting is volgens de Hoge Raad niet zonder meer sprake van voorwaardelijk opzet op het toebrengen van zwaar lichamelijk letsel. ${ }^{2}$ Bovendien kunnen factoren die buiten de macht van de verdachte liggen, zoals onbeschermde seksuele contacten van het slachtoffer met derden, de oorzaak van de besmetting zijn, waardoor het bewijs van causaal verband problematisch kan zijn. In een dergelijk geval kan nog wel sprake zijn van poging tot zware mishandeling wanneer die poging plaatsvindt door het bewust toedienen van besmet bloed met injectienaalden. ${ }^{3}$

Klaas Rozemond is universitair hoofddocent strafrecht aan de Vrije Universiteit Amsterdam.

1 HR 25 maart 2003, ECLI:NL:HR:2003:AE9049, NJ 2003/552 m.nt. Y. Buruma en HR 18 januari 2005, ECLI:NL:HR:2005:AR1860, NJ 2005/154 m.nt. D.H. de Jong.

2 HR 20 februari 2007, ECLI:NL:HR:2007:AY9659, NJ 2007/313 m.nt. Y.Buruma.

3 HR 27 maart 2012, ECLI:NL:HR:2012:BT6362, NJ 2012/301 m.nt. N. Keijzer.
De restrictieve rechtspraak van de Hoge Raad over hiv-besmetting heeft tot gevolg gehad dat personen die met het hiv-virus zijn besmet en onbeschermde seks hebben met anderen, bijna niet strafrechtelijk kunnen worden vervolgd, hoewel de strafrechtelijke mogelijkheden daartoe niet helemaal zijn uitgeput. Zo is niet uitgesloten dat een besmet persoon bij een onbeschermd seksueel contact het oogmerk heeft om een ander te besmetten. Anders dan bij voorwaardelijk opzet geldt bij een bewezen oogmerk wellicht niet de eis dat de kans op besmetting aanmerkelijk was, hoewel de opvattingen hierover in de literatuur verdeeld zijn. ${ }^{4}$ Bovendien kan voorwaardelijk opzet worden afgeleid uit bijzondere, risicoverhogende omstandigheden, zoals de weigering van de verdachte om virusremmende medicatie te gebruiken. ${ }^{5}$ Ook is veroordeling voor het toebrengen van zwaar lichamelijk letsel door schuld of roekeloosheid (art. $308 \mathrm{Sr}$ ) niet uitgesloten wanneer kan worden bewezen dat de verdachte een ander heeft besmet bij onbeschermde seks. ${ }^{6}$

Bovendien heeft de Hoge Raad in een later arrest aangegeven dat een aanmerkelijke kans een reële kans betekent. De kans op besmetting met hiv is bij een onbeschermd seksueel contact met een besmet persoon wellicht niet aanmerkelijk te noemen. In het licht van de cijfers over de hiv-epidemie is het echter moeilijk vol te houden dat de kans op besmetting niet reëel is. ${ }^{7}$ Ik denk

J. de Hullu, Materieel strafrecht, achtste druk, Deventer: Kluwer 2021, p. 231. Rb. Zeeland-West-Brabant 23 maart 2020, ECLI:NL:RBZWB:2020:1351. In de zaak van Rb. Zeeland-West-Brabant 23 maart 2020, ECLI:NL: RBZWB:2020:1351is subsidiair het veroorzaken van zwaar lichamelijk letsel door schuld ten laste gelegd (art. $308 \mathrm{Sr}$ ).

7 Aidsdoden sinds begin van de epidemie: 36,3 miljoen, Aidsdoden in 2020 680.000 , aantal mensen met hiv: 37,7 miljoen, percentage op levensreddende behandeling: 73\%, aantal nieuwe infecties in 2020: 1,5 miljoen. Bron: https://aidsfonds.nl/over-hiv-aids/feiten-en-cijfers/ (geraadpleegd op 8 september 2021). 
daarom dat voorwaardelijk opzet niet zuiver kwantitatief kan worden benaderd, zoals de Hoge Raad met het begrip aanmerkelijk heeft willen doen. ${ }^{8} \mathrm{Bij}$ de beantwoording van de vraag of een verdachte opzettelijk heeft gehandeld, moet ook de maatschappelijke context waarin een verdachte handelt worden betrokken en de betekenis en gevolgen van zijn handelen in die context.

$\mathrm{Bij}$ een contextuele uitleg van het voorwaardelijke opzet zou ook de huidige corona-epidemie een rol kunnen spelen en de rechtspraak over coronaspugers en coronahoesters die strafrechtelijk worden veroordeeld. Uit die rechtspraak blijkt dat rechtbanken, gerechtshoven en de Hoge Raad een extensieve opvatting hebben over de mogelijkheid om deze spugers en hoesters strafrechtelijk te veroordelen vanwege de ernst van het coronavirus en de risico's op besmetting bij spugen en hoesten. Het gaat daarbij niet alleen om de kwantitatieve grootte van de risico's bij een afzonderlijk hoest- of spuugincident, maar ook om de betekenis en de gevolgen daarvan in de maatschappelijke context van de corona-epidemie. In die context kunnen bepaalde gedragingen als zeer gevaarzettend worden beschouwd, ook al is het werkelijke gevaar in afzonderlijke gevallen niet groot te noemen. ${ }^{9}$ Veroordeling van spugers en hoesters vindt niet plaats op basis van mishandeling ${ }^{10}$ of poging tot zware mishandeling, maar op grond van bedreiging met zware mishandeling (art. $285 \mathrm{Sr}$ ). Ook die strafbepaling roept rechtsvragen op over de aard van de coronabesmetting (wel of geen zwaar lichamelijk letsel?), het risico op besmetting van de slachtoffers (wel of geen reëel risico?) en de daarmee samenhangende vrees (wel of geen redelijke vrees voor besmetting?). Spugen en hoesten kan in tijden van corona als zeer gevaarzettend gedrag worden beschouwd waardoor de redelijke vrees voor besmetting wordt opgewekt. In zijn hiv-rechtspraak gaf de Hoge Raad aan dat gevaarzettend gedrag op zich nog geen aanmerkelijke kans op verwezenlijking van het gevaar oplevert. ${ }^{11}$ Ook oordeelde de Hoge Raad dat de aard van het gevolg niet bepalend is voor de vraag of de kans op het gevolg aanmerkelijk is te noemen. ${ }^{12}$ Deze uitgangspunten lijkt de Hoge Raad te hebben losgelaten in de context van de coronacrisis: gevaarzettend gedrag zoals spugen en hoesten in de richting van een ander kan een strafbare vorm van bedreiging met zware mishandeling zijn, waarbij de ernst van het gevaar en de mogelijkheid van besmetting bepalend zijn voor de strafbaarheid van de gedraging. De Hoge Raad heeft echter nog geen bevredigende antwoorden gegeven op alle rechtsvragen over bedreiging met coronabesmetting.

Zie voor een contextuele benadering Rb. Rotterdam 9 april 2020, ECLI: NL:RBROT:2020:3338.

10 Zie bijvoorbeeld Rb. Amsterdam 14 mei 2021, ECLI:NL:RBAMS:2021: 2405 en ECLI:NL:RBAMS:2021:2402: vrijspraak van een coronaspuger voor mishandeling.

11 R.o. 3.6 in HR 18 januari 2005, ECLI:NL:HR:2005:AR1860, NJ 2005/154 m.nt. D.H. de Jong.

12 R.o. 3.6 in HR 25 maart 2003, ECLI:NL:HR:2003:AE9049, NJ 2003/552 m.nt. Y. Buruma.

\section{Rechtsvragen bij bedreiging}

In de zaak die leidde tot het eerste arrest van de Hoge Raad over een coronaspuger ${ }^{13}$ had de aangehouden verdachte in een politiebureau in de richting van enkele agenten gespuugd. De afstand van de verdachte tot de agenten was drie à vier meter en het spuug van de verdachte kwam op ongeveer twee meter van de agenten op de grond terecht, ruim buiten de anderhalve meter die mensen in acht moeten nemen bij hun contacten met anderen om besmetting met corona te voorkomen. Die anderhalve meter geldt echter voor mensen die niet in de richting van anderen spugen of hoesten. Het is onduidelijk wat de kans op besmetting is in het geval van een persoon die op een afstand van drie à vier meter in de richting van anderen spuugt. Een risicoverhogende factor is dat het spugen plaatsvindt in een afgesloten ruimte waarbij de besmetting zou kunnen plaatsvinden door zwevende virusdeeltjes (aerosolen). ${ }^{14}$

Over het voorwaardelijke opzet bij de verdachte en de redelijke vrees voor besmetting bij de slachtoffers overwoog de Hoge Raad:

'3.4.2 Het hof heeft geoordeeld dat bij de verbalisanten [verbalisant 3], [verbalisant 4], [verbalisant 5] en [verbalisant 6] in redelijkheid de vrees kon ontstaan dat zij zwaar lichamelijk letsel zouden kunnen oplopen. Daarbij heeft het hof in aanmerking genomen dat het coronavirus Nederland ten tijde van het bewezenverklaarde - 26 april 2020 - al wekenlang in zijn greep had terwijl er op dat moment nog veel onzekerheden waren over de aard en de verspreiding daarvan. Verder heeft het hof geoordeeld dat de verdachte, gelet op zijn voor het bewijs gebruikte verklaring, bewust de aanmerkelijke kans heeft aanvaard dat bij de verbalisanten in redelijkheid die vrees kon ontstaan. Deze oordelen getuigen, gelet op wat onder 3.3 is vooropgesteld, niet van een onjuiste rechtsopvatting en zijn in het licht van de onder 3.4.1 weergegeven vaststellingen niet onbegrijpelijk.'

In deze overweging acht de Hoge Raad relevant dat 'het coronavirus Nederland al wekenlang in zijn greep had'. Op het moment van het gepleegde feit (26 april 2020) waren er 'nog veel onzekerheden over de aard en de verspreiding daarvan', aldus de Hoge Raad. Kern van de vrees bij de slachtoffers was dat 'zij zich zorgen over hun gezondheid maakten vanwege de mogelijke besmetting van het coronavirus, al dan niet door de nevel van het speeksel', zo blijkt uit het proces-verbaal van een van de verbalisanten. ${ }^{15}$

De eerste rechtsvraag die de overweging van de Hoge Raad oproept, heeft betrekking op de aard van bedreiging als misdrijf tegen de persoonlijke vrijheid. Bij een dergelijke bedreiging gaat het meestal om twee fasen. In

13 HR 9 februari 2021, ECLI:NL:HR:2021:190, NJ 2021/171 m.nt. P.A.M. Mevis.

14 www.rivm.nl/coronavirus-covid-19/verspreiding (geraadpleegd op 6 september 2021).

15 HR 9 februari 2021 a.w., r.o. 2.2. 
de eerste fase bedreigt de dader het slachtoffer met zware mishandeling, bijvoorbeeld door aan te kondigen dat hij of zij het slachtoffer zwaar gaat mishandelen. Door die aankondiging kan bij het slachtoffer de vrees ontstaan dat de dader in de aangekondigde tweede fase daadwerkelijk tot zware mishandeling zal overgaan. In dit geval lijkt bij de agenten echter niet de vrees te zijn opgewekt dat de verdachte na het spugen zou overgaan tot zware mishandeling in een tweede fase. De zorgen van de agenten betroffen het risico op besmetting door het eerste spugen op zich. Uit deze zaak blijkt echter niet dat die zorgen zo groot waren dat de agenten zich op corona hebben laten testen vanwege het spuugincident. ${ }^{16}$

Dat roept de rechtsvraag op of die zorgen een redelijke vrees voor het opzettelijk toebrengen van zwaar lichamelijk letsel waren. Advocaat-generaal Bleichrodt beantwoordt deze vraag negatief. Uit de bewijsmiddelen kan in dit geval niet worden afgeleid dat de verdachte 'de vrees wekte nogmaals - en van geringere afstand te zullen spugen of anderszins contact te zullen opzoeken waaruit een verhoogd risico op besmetting zou kunnen voortvloeien'. Kennelijk ging het hof er in dit geval van uit dat het eerste spugen op zich al de redelijke vrees voor zwaar lichamelijk letsel door dat spugen kon veroorzaken bij de agenten, maar die opvatting is volgens Bleichrodt zonder nadere motivering niet begrijpelijk. ${ }^{17}$

Op dit punt van de advocaat-generaal gaat de Hoge Raad niet in. De Hoge Raad wekt daardoor de indruk dat de enkele vrees voor besmetting ten gevolge van het spugen van een relatief grote afstand (drie tot vier meter) al voldoende is voor een bewezenverklaring van bedreiging. De vrees hoeft derhalve geen betrekking te hebben op een tweede fase waarin de verdachte daadwerkelijk overgaat tot een eerder aangekondigde zware mishandeling in de vorm van spugen of hoesten binnen anderhalve meter in het gezicht van een ander. Ook is niet relevant dat de verdachte geen dreigende uitlatingen doet met de strekking dat hij de verbalisanten zou gaan besmetten met corona. ${ }^{18}$

Het ontbreken van dreigende uitlatingen is een argument om ook te twijfelen aan het opzet van de verdachte op bedreiging van de agenten. ${ }^{19}$ Uit het spugen op zich kan niet zonder meer worden afgeleid dat de verdachte 'bewust de aanmerkelijke kans heeft aanvaard dat bij de verbalisanten door het op afstand spugen in redelijkheid de vrees kon ontstaan dat zij zwaar lichamelijk let-

16 Vgl. Rb. Dordrecht 20 september 2007, ECLI:NL:RBDOR:2007:BB4084 agenten hebben zich op hiv laten testen na een spuugincident in een politiebusje.

17 Punt 34 in de conclusie (ECLI:NL:PHR:2020:1152) bij HR 9 februari 2021, a.w.

18 Zie de rechtspraak die de raadsman van de verdachte vermeldde in zijn pleidooi, weergegeven in r.o. 3.2.1 in het arrest van de Hoge Raad waarin het aspect van dreigende uitlatingen wel relevant werd geacht. Zie ook Hof 's-Hertogenbosch 20 april 2020, ECLI:NL:GHSHE:2020:1393, Hof Arnhem-Leeuwarden 29 mei 2020, ECLI:NL:GHARL:2020:4122 en Hof Arnhem-Leeuwarden 3 november 2020, ECLI:NL:GHARL:2020:8952.

19 Vgl. Rb. Amsterdam 15 januari 2021, ECLI:NL:RBAMS:2021:444. sel zouden oplopen'. ${ }^{20}$ Uit de verklaring van de verdachte kan wel worden afgeleid dat hij 'wist van de ernst van het coronavirus en de mogelijkheid dat dit zich via speeksel door de lucht verspreidt'. ${ }^{21}$ Die wetenschap houdt echter nog geen opzet in op het ontstaan van redelijke vrees bij de agenten dat zij zwaar lichamelijk letsel zouden oplopen door het spugen op afstand. 'Uit de enkele omstandigheid dat die wetenschap bij de verdachte aanwezig is, kan niet zonder meer volgen dat hij de aanmerkelijke kans op het gevolg ook bewust heeft aanvaard', aldus de Hoge Raad in 2003 in verband met de kans op een hiv-besmetting. ${ }^{22}$ In de context van de coronacrisis en het misdrijf bedreiging lijkt de Hoge Raad daarover een ruimere opvatting te aanvaarden als het gaat om opzet op het veroorzaken van vrees voor besmetting.

Uit de bewijsmiddelen blijkt ook niet dat besmetting met corona zwaar lichamelijk letsel is. Alleen bij bepaalde risicogroepen is de kans op ernstige gevolgen (ziekenhuisopname, opname op de intensive care, overlijden) aanmerkelijk te noemen. ${ }^{23}$ Besmetting met een virus zoals het hiv-virus kan volgens de Hoge Raad wel zwaar lichamelijk letsel opleveren in de vorm van 'ernstige lichamelijke schade aan de gezondheid'. ${ }^{24}$ Het is echter de vraag of besmetting met het coronavirus op zich kan worden opgevat als ernstige lichamelijke schade aan de gezondheid. Een relevant verschil met het hiv-virus is immers dat een coronabesmetting in de meeste gevallen binnen enkele dagen verdwijnt door de werking van het natuurlijke afweersysteem van mensen. In lagere rechtspraak zijn wel argumenten te vinden waarom een coronabesmetting zwaar lichamelijk letsel kan opleveren, bijvoorbeeld het argument dat een coronabesmetting ernstige klachten kan veroorzaken waarbij medisch ingrijpen noodzakelijk is, het herstel lange tijd in beslag kan nemen en de kans dat een besmet persoon in het ziekenhuis moet worden opgenomen en mogelijk op de afdeling intensive care belandt aanmerkelijk is in de zin van reëel. ${ }^{25}$ Deze overweging laat onbedoeld het verschil zien tussen een aanmerkelijke en een reële kans. De complicaties na een coronabesmetting doen zich slechts in een beperkt aantal gevallen voor. Daarom is het niet zonder meer duidelijk waarom de kans op complicaties bij iedereen die wordt besmet aanmerkelijk is te noemen. De kans op medische complicaties is echter wel reëel, zo wijst het verloop van de corona-epidemie uit. ${ }^{26}$ Daaruit zou kunnen worden af-

20 Punt 43 van de conclusie van A-G Bleichrodt, a.w.. Zie ook Hof Den Haag 1 december 2020, ECLI:NL:GHDHA:2020:2371

21 R.o. 3.4.1 in het arrest van 9 februari 2021, a.w.

22 R.o. 3.6 in HR 25 maart 2003, ECLI:NL:HR:2003:AE9049, NJ 2003/552 m.nt. Y. Buruma.

23 www.rivm.nl/coronavirus-covid-19/risicogroepen (geraadpleegd op 8 september 2021).

24 R.o. 3.4 in HR 3 juli 2018, ECLI:NL:HR:2018:1051, NJ 2020/200 m.nt. H. Wolswijk.

25 Rb. Limburg 5 augustus 2020, ECLI:NL:RBLIM:2020:5758) en Rb. Den Haag 20 maart 2020, ECLI:NL:RBDHA:2020:2766. Vgl. r.o. 2.4 en 2.8 in HR 3 juli 2018, ECLI:NL:HR:2018:1051, NJ 2020/200 m.nt. H. Wolswijk.

26 Zie voor de relevante cijfers https://coronadashboard.rijksoverheid.nl (geraadpleegd op 8 september 2021). 
geleid dat er toch een verschil bestaat tussen een aanmerkelijke kans en een reële kans.

De kans op complicaties wordt ook bepaald door nieuwe medische ontwikkelingen. In een vonnis van 20 maart 2020 overwoog de Rechtbank Den Haag dat het om een virus gaat 'waarvoor nog geen medicijn is'. ${ }^{27}$ Dat is na de ontwikkeling van vaccins echter anders, zodat nu ook de vraag of slachtoffers gevaccineerd zijn relevant kan zijn voor de redelijkheid van de vrees voor zwaar lichamelijk letsel na een confrontatie met een coronaspuger of coronahoester en het voorwaardelijke opzet daarop van de spuger of de hoester. De kans op medische complicaties na besmetting is door vaccinaties aanzienlijk kleiner geworden, wat niet wegneemt dat de kans daarop nog steeds reëel is.

\section{Conclusie: van kwantitatieve naar contextuele benadering}

De restrictieve uitleg van het voorwaardelijke opzet in verband met hiv-besmetting was mede gebaseerd op de terughoudende opstelling van de verantwoordelijke bewindslieden ten opzichte van de strafrechtelijke bestrijding van onbeschermde seksuele contacten door met hiv besmette personen. ${ }^{28}$ Een vergelijkbare terughoudendheid kan niet worden vastgesteld bij de huidige bewindslieden die verantwoordelijk zijn voor de bestrijding van de corona-epidemie. Ook de aard van de handelingen kan daarbij een rol spelen. In hiv-zaken gaat het om vrijwillige seksuele contacten waarbij bepaalde risico's bestaan voor de gezondheid van de betrokkenen. In de coronacrisis gaat het om spugen en hoesten met de bedoeling om anderen angst aan te jagen voor hun gezondheid. ${ }^{29}$ Het is echter de vraag of deze verschillen een ruimere strafrechtelijke aansprakelijkheid van hoesters en spugers tijdens de coronacrisis kunnen rechtvaardigen in vergelijking met personen die met hiv zijn besmet en onbeschermde seksuele contacten hebben. Wellicht is de strafrechtelijke benadering van de hiv-epidemie te restrictief, maar ook bij een extensieve benadering moeten bepaalde grenzen in acht worden genomen.

Bij de corona-epidemie zouden die grenzen in beginsel binnen de fysieke afstand van de anderhalve meter kunnen worden getrokken. Dat is te verdedigen op grond van gangbare definities van voorwaardelijk opzet, redelijke vrees en zwaar lichamelijk letsel. Zorg om een mogelijke besmetting door zwevende virusdeeltjes na spugen van relatief grote afstand is nog geen redelijke vrees voor zwaar lichamelijk letsel en hoesten of spugen buiten de anderhalvemetergrens impliceert nog geen voorwaardelijk opzet bij de spuger of hoester op het ver- oorzaken van een dergelijke vrees. Daarvoor is wellicht meer vereist, zoals het hoesten of spugen in het gezicht van het slachtoffer onder het uiten van dreigende taal met de strekking dat de dader het slachtoffer gaat besmetten. En dan nog is het de vraag of in dergelijke gevallen de vrees voor zwaar lichamelijk letsel zonder meer redelijk is. Een besmetting met corona zonder medische complicaties is immers geen zwaar lichamelijk letsel en de vrees voor dergelijke complicaties is wellicht niet meer redelijk te noemen wanneer de slachtoffers zijn gevaccineerd of behoren tot de vaccinatieweigeraars die de vrees voor corona overdreven vinden. Mensen in de risicogroepen bij wie de vaccins niet werken, verdienen echter wel strafrechtelijke bescherming tegen spugers en hoesters die weten dat zij deze specifieke slachtoffers vrees kunnen aanjagen voor medische complicaties na besmetting en daarom welbewust in hun gezicht spugen of hoesten. 